\title{
A Negative Theological Critique of Postmodern Identity Politics
}

\author{
William Franke \\ College of Art and Science, Vanderbilt University, Nashville, TN 37235, USA; william.franke@vanderbilt.edu
}

Received: 15 July 2019; Accepted: 14 August 2019; Published: 19 August 2019

\begin{abstract}
This paper leverages the Christian tradition of negative theology (Gregory of Nyssa, Dionysius the Areopagite, Eriugena, Eckhart, Cusanus) in order to think past the impasses of identitarian politics and culture. It essentially bears on Christianity and on literary imagination by valorizing their focus on the mystery of who we are beyond all divisive identities and on how an orientation to negative-theological transcendence can save us from a toxic obsession with identities in a postmodern, postcolonial, post-gender society.
\end{abstract}

Keywords: negative theology; identity; non-identical; Enlightenment

\section{Introduction}

In what we are now used to calling postmodern times, discourses about race, class, and gender are characteristically fraught with ambiguity. Various unprecedented gender identities and new forms of ethnic or racial consciousness have emerged in these dynamic times and have asserted themselves irrecusably in concrete ways. In spite of sometimes bitter resistance, they have succeeded in claiming political rights, gaining economic power, and acquiring social legitimacy. The consequent social revolution is manifest in a wide spectrum of sociological phenomena ranging from a new female workforce restructuring previously all-male professions, new minority middle classes, and unprecedentedly large immigrant populations, notably in Europe, to gay and lesbian matrimony and the going-public of alternative, hybrid genders displaying their differences in transvestite performances and drag shows. Even institutionalized declaration of one's preferred "pronouns" has contributed to promoting recognition of public gender identification as a matter of free choice for the individual rather than simply a natural fact of being either male or female. Official documents and public facilities increasingly allow for more than just the traditional gender binary. Many new voices have spoken up, moreover, on behalf of racial or ethnic minorities and have highlighted their cultural distinctness, even in making a bid to be recognized as fully integral components of a now unmistakably multiracial, multicultural, multigender society.

While such conspicuous and colorful new identities have successfully insinuated themselves, infiltrating particularly into the bastions of the academy, at the same time, the idea of identity has been eroded from within by the very logic or illogic of postmodern thinking, which does not take any identity as more than an arbitrary invention or convention. A new post-essentialist epistemology exposes identity as being at most a purely heuristic construct. The hard-nosed identity politics of the 1960s have come to seem outdated, if not unproductive, after the pervasive deconstructions of identity that gained ever-greater currency, especially through the 1980s and 1990s. Yet, the proliferation of new claims to identity goes on unabated.

Can some strands of postmodern theory afford critical insight into and increased sensitivity towards what identity and its claims consist in? Such theoretical reflection should serve at least to sharpen our awareness of the ultimate indefinability of our true identity. Whatever it is that makes 
human beings what they are is, in the end, not reducible to identical terms (Heller-Roazen 2017). ${ }^{1}$ So far, perhaps, most of us working in the academy today, and in variously theoretical disciplines, tend to agree. However, widely divergent pedigrees for this kind of insight can be produced, and the stated consensus concerning the ultimate indefinability of identity turns out to be the premise for what could well threaten to precipitate apparently irresolvable controversy.

My purpose here is not to take sides in such controversy, but rather to light up the normally invisible background of the non-identical against which all identity claims are implicitly projected. There is something absolute in the background here that relativizes all identity claims which otherwise tend toward absolutization of their own claims in their own inevitably partial, oppositional terms. We are duped into seeing only competing identities on the field, and the rest, including the field itself, sinks below the threshold of perception. Then, conflicts become irresolvable and tragic. The absolute value of persons actually resides in an invisible depth or unarticulable height, above and before any differentiation into exclusionary identities. The following reflections attempt to hold up the dilemmas of identity to this unapparent light as necessary for keeping cultural identity politics in perspective.

There are, of course, many sorts of critiques of identity. Anti-identitarian thinking seems at first to belong to radical and iconoclastic movements aiming to liberate individuals from static myths inherited from the past and purportedly fixed in stone by tradition. Ironically, however, this emancipatory vision can also be cast in apparently traditional theological terms through reference to the image of God. A towering historical landmark here is Pico della Mirandola's De dignitate homini (1486), with its scene of the Creator endowing humans with no gift. Having given all away already to the animals, he has nothing left to give to humans except for free choice-an undetermined capacity to choose for oneself what one will become.

Our being made in the image of an infinite God entails, at the same time, our being infinitely open and indefinable as any sort of identical individual or essential nature. This is the consequence of God's infinity, which no language or knowledge can adequately encompass. More precisely, a deeper insight into the non-identity of individuals derives from negative theology, that is, from the admission that God is unknowable in any definable concepts or terms (Franke 2007). ${ }^{2}$ In classical negative theologians such as John Scott Eriugena and Gregory of Nyssa, the unknowability of God extends to the unknowability, and thus also to the non-identity of individuals in general in their deepest core. What defines human nature is paradoxically its lack of any essential defining characteristics (Carlson 2008; Franke 2007, pp. $140-51,181-90) .^{3}$

The pervasive, almost irresistible privileging of what can be defined and specified and claim rights for itself in a democratic society supposedly based on argument and rational justification, including self-justification, entails certain liabilities engendering optical illusions or epistemic biases and susceptibilities to being abused. The focus on definable identities proved itself historically to have been necessary for social progress—in particular for reversing overt and covert identity-based discrimination. However, it has also led to some systemic distortions. For not only those whose identity can be well defined have needs and a claim to protection and respect. In the overall scheme of things, those who have not yet come to a highly developed degree of conscious, sometimes even combative, awareness of self are just as important and often even more in need of benign fostering. There are certain important parts and aspects of us all that have no individuated, isolable identity. Yet, in the politics of identity, only those identifiable as belonging to some definite group are recognized as warranting protection and perhaps even compensatory privileges. In these artificially created

\footnotetext{
Heller-Roazen (2017), places the endless openness to infinity of human identity in a long historical perspective.

I reconstruct this tradition in (Franke 2007, vol. 1).

Carlson (2008), explores the anthropological relevance of John Scott Eriugena and other negative theologians to the argument that humanity is without any definable identity. I treat this motif of negative theologians including Eriugena in (Franke 2007, vol. 1, pp. 181-90). Gregory of Nyssa, also treated in this volume (pp. 140-51), develops kindred insights into human infinity and consequent unknowability under the heading of "epektasis" or "endless striving."
} 
circumstances, if you do not have a label, you hardly exist at all. Only a socially marketable or politically appreciable distinctive identity can give you a publicly recognized status or "face." Without this, in a society based more and more on positive and politicized identities, you have no social capital and no political leverage. You are no one, at least no one special having a claim to attention and benevolent encouragement and patronage. This, too, builds invidious biases into the social system and its communicative practices.

\section{Competing Genealogies of Identity Claims}

In order to make a case for the non-identical, and to defend those persons and aspects of life and existence that fall below the threshold of identity and its claims, we need to critically examine the basis for the widespread vindication of identity in contemporary society. It proves to be complex. A contradictory confluence of inspirations and derivations, with their different genealogies, makes the agenda of these identity-driven ideologies based on regional, gender, class, or special-interest groups and movements conflictual, or at least confusing.

Are these ideologies of identity informed by the structuralist insight into the relativity of all oppositional terms that lies at the foundation of the critical theory revolution of the last several decades, especially since the 1960s and 1970s? Ferdinand de Saussure famously proclaimed, with far-reaching consequences, that in language there are only differences without positive terms. This insight was carried over and applied to culture generally by, among others, Roman Jakobson in linguistics, Claude Levi-Strauss in anthropology, and Roland Barthes in cultural semiotics. This structuralist theoretical paradigm entailed the valorization of difference-and consequently the self-assertion of their different identities by non-mainstream groups under the banner of their being different but not less valuable or less worthy of entitlement than those belonging to majority identity groups. The advocacy of difference became central to the agenda of French poststructuralist philosophers, such as Jacques Derrida and Gilles Deleuze (Derrida 1967; Deleuze 1968).

Alternatively, are the new ideologies of identity beholden, rather, to the Enlightenment ideal of promoting freestanding individuals? This latter agenda has also been of the utmost importance in fueling a wide spectrum of liberation movements since the 1960s (Flax 1993; Hooks 1990). ${ }^{4}$ The assumptions of the Enlightenment have been placed under a heavy pressure of critique within the ambit of theory, especially postmodern theory, which is generally anti-Enlightenment in its premises and persuasions since Enlightenment was in crucial ways the leading project of modernity. Even the philosophy of the Frankfurt school itself, for all its continuity with Enlightenment thinking, made programmatic especially in Jürgen Habermas' thought, was based on a deep sense of the ambiguities inherent in the dialectic of Enlightenment. In this perspective, the Enlightenment was charged with producing myths of its own and thereby leading to the totalitarianisms of consumer society and mass media culture steered by capitalist interests (Adorno and Horkheimer 1944).

Some recent revisions of identity theory register the backlash against identity politics from left, right, and center, both within the academy and within political movements themselves (Alcoff et al. 2006; Hall 2003). ${ }^{5}$ These new identity theorists attempt to defend identity politics and even a certain realist theory of identity. Such revisionist efforts take stock of a certain reversal of the positive valence of identity in the discourse surrounding the liberation movements on behalf of disenfranchised minorities of a few decades earlier (Sen 2006). ${ }^{6}$ They admit the anti-essentialist arguments showing that identities are socially constructed, but they nevertheless insist that "identities can be no less real for being socially and historically situated" (Alcoff et al. 2006, p. 6). In the end, these authors wish to defend the concept of identity and its relevance, despite the recent critiques

\footnotetext{
Flax (1993) and Hooks (1990) count among innumerable influential representatives of this tendency.

Compare also Hall (2003, pp. 1-17).

The widespread questioning of aggressive identity politics is given urgent formulation by Sen (2006).
} 
provoked by its excesses. "We believe that these critiques of identity are largely mistaken, too often based on anecdotes about incidents where specific groups used poor political judgment rather than empirical studies of identity-based movements from which a larger analysis of their effects can emerge" (Alcoff et al. 2006, p. 3). Like Habermas in his The Philosophical Discourse of Modernity (Habermas 1985), such new proponents of identity turn away from the dominant trends of postmodernism in order to reaffirm something of a classic modern vision of progressive social liberation. But this (liberal) ideology works only to the extent that it can be valid for all, above and beyond all determinate communitarian identities. In other words, it works only so long as all individuals can identify themselves with a common vision or destiny such as the proverbial American dream.

Especially dear to the ideology of the Enlightenment is the discovery that individuals are valuable in themselves and not only in their relations within the social order, in which they are good for performing useful functions by delivering differentiated services such as those of butcher, baker, or candlestick maker. The individual's deepest or highest value is not functional, but absolute. Human persons are "ends-in-themselves" in a jargon handed down from Enlightenment philosopher Immanuel Kant (1724-1804). Historically, the Bible and Judeo-Christian culture have played a key role in bringing about this affirmation of the unconditional value of the individual person. In Saint Paul's terms, the individual is no longer essentially qualified as male or female, slave or free, Greek or Jew (Galatians 3: 28). All are equally and infinitely valuable in the sight of God. Such a notion of unconditioned individual identity and worth emerges as a concept historically from theological discourse.

Paul's role here has been key to recent discussion among philosophers of the unconditional or universal value of the individual (Boyarin 1994; Caputo and Scanlon 2007; Caputo and Alcoff 2009; Milbank et al. 2010). Alain Badiou has turned to Paul as the antidote to the particularisms and sectarianisms that plague society in our historical moment and make it all the more vulnerable to manipulation by capitalist interests exploiting mass markets (Badiou 1997, pp. 5-16). Equally provocatively, Giorgio Agamben has analyzed Paul's revolutionizing of the logic of identity in the context of his political theology (Agamben 2000). Being Christian can be construed as a matter of being "not not Jewish," for in the Christian testament, the revelation to the Jews becomes relevant even for those who are not Jews. Christians are not entirely not Jews to the extent that their revelation is based on the Jewish testament. Both Jews and Gentiles are displaced from their settled, exclusive identities by the call to faith in the Gospels that cuts across this and all other divisions of identity.

Judeo-Christian culture in this instance intervenes to interrupt the tradition of logical thinking hailing from Greece by introducing irreducible singularities that exceed all terms of identity. Hence the recovery of this "other" tradition for philosophy by thinkers such as Adorno and Levinas, who are following in the footsteps of religiously inspired reactions to the Hegelian system by Schelling and Kierkegaard (De Vries 1989, 1999; Franke 2007). More recently, Slavoj Žižek and Eric Santner have leveraged Judeo-Christian tradition for similar purposes (Žižek 2000; Santner 2015). Žižek redeploys a heterodox Christian theology in his reopening of the question of universality beyond the politics of identity. Actually, however, the aporiae of Greek thought in the late Neoplatonists, particularly Proclus and Damascius, can be shown already to point in this direction of undermining identity (Franke 2007, pp. 75-107). Indeed, these insights into the limits of identity are culturally universal. Axial Age cultures across the planet already envisaged such a transcendent universality that exceeded the grasp of finite rationality.

Nevertheless, biblical tradition certainly plays a key role in this regard in the West. The Bible declares that Adam was made in the image of God. When God became something of a dubious hypothesis among Enlightenment thinkers, the human individual, newly discovered in previously unsuspected freedom and potential for self-realization, stepped forward in a bright new light. Without a transcendent foundation for value, the autonomous Enlightenment individual in important ways became an absolute value in him or herself. (The generic individual, at this stage in modern history, was usually designated as he, although many women, beginning at least with the revolutionary so-called "tricoteuses" ["knitters"], were in fact exceedingly active and influential in disseminating 
the new outlook.) Individual identity and the autonomy it claims are themselves in crucial ways the invention of the Enlightenment, although the basis for them is borrowed from biblical religion and ethics, especially as interpreted by Protestantism since the sixteenth century, with its emphasis upon the single individual standing directly face to face with God (Weber 1992). ${ }^{7}$

Monotheist theology offered the description of God as the source and ground of all being. God alone is unconditioned being. All else is derived from him and is therefore conditioned being. In the emancipatory moment of Enlightenment, however, absolute value was transferred from God to the human individual (Taylor 1984). ${ }^{8}$ This was already implicit in the proclamation of the Incarnation-that God became man. Such was the central thrust of Christianity for Enlightenment thought, as one can see, for example, from Hegel's philosophy of religion and even more unambiguously in the liberal theology of Adolf von Harnack, celebrating the man Jesus as moral teacher. But with this absolutization of the ethical and the human, the problem arises (or becomes acute) of a plurality of absolutes or of claims to be valuable in oneself and not only in relation to some greater whole within which one functions. The claim to self-grounded, self-sufficient, self-generating value persists, but now in a fractured world, where all is no longer placed under the one supreme, unique source of value affirmed by monotheism. The death of God was definitively the birth of the autonomous individual self with a claim to unconditional value. Theoretically, each individual is an origin of unconditioned value in and for herself or himself, just as theologically, God is the unconditioned, ultimate source of good. In practice, however, rights and privileges for human individuals can only be granted and guaranteed on a very relative basis. Each person's absolute value is, in fact, qualified and severely restricted by that of everyone else because each other person has exactly the same claim to being valued absolutely for him or herself alone.

The gain in intrinsic value for the individual was at the same time, in effect, a loss of value based on the individual's playing a part in a greater whole. Our modern Western, emancipated societies are crippled by this breakdown of the necessary, or at least the enabling, conditions for solidarity in the community. This registers dramatically in various cultural expressions of existential Angst, for example, in Expressionist paintings like Edvard Munch's “The Scream," or in Martin Heidegger's analysis of the "thrownness" (Geworfenheit) of human existence. Certain consequences of existential despair are drawn out in the argument for suicide as made by Albert Camus in Le mythe de Sisyphe (1942). The modern, supposedly liberated and apparently valorized individual is also devalued by being made valuable only for him or herself alone: $\mathrm{s} / \mathrm{he}$ has no foundation for his or her attempt to be and to be significant. What worked for God is very difficult for a human individual to pull off or sustain. To create and emanate value from oneself alone is divine, but the human way can only be to create and transmit value through interacting with others. Humans become valuable by serving purposes more significant than themselves. Existing for themselves alone as mere particulars rather than in relation to always larger wholes, they are liable to reduce and deflate to vain pretense and empty ciphers.

\section{Competing Claims and Rights of Individuals}

Enlightenment ideology has encouraged and keeps encouraging individuals, nevertheless, whether alone or in groups, to claim unconditional value for themselves. The premise of this claim is that every individual is entitled to the full privileges of value-in-him-or-herself. This is what Kant in his moral philosophy called being an "end-in-oneself" (Zweck-an-sich). This assumption leads to movements of various types militating for the rights of individuals of one group or another that for no good reason seem to be denied the rights and privileges of being valued for their own sake alone. These movements are typically powered by energies of self-assertion: they focus on class interests as extensions of self-interest that is expanded and made collective. Their common premise is the

7 A classic text here is (Weber (Weber 1992).

8 This genealogy is suggestively traced by Taylor (1984). 
Enlightenment valorization of the individual as such and without necessary relation to anything greater or more important.

There is in this ideology of the individual an absoluteness and inviolability about each singular I that is at least quasi-religious and that would even be marked culturally by some as particularly Christian. As unconditional, the value of the individual person is derived or borrowed from the absolute value of a Supreme Being or divinity. And yet, in human reality, all rights for any group or individual must be negotiated against the rights of others. This cannot be avoided in the social context, even though it did not apply in the theological context, where the monotheistic God is indeed without equal, truly the one and only. Therefore, as we translate this idea of being valuable in and for oneself from a theological to a secular register, we need an appreciation not just of the unconditionality, but also of the relativity of rights. Every individual does have an infinite dignity and worth, but not in virtue of their identity as defined differentially against others' identities. This unconditional worth can only be based on that which in the individual cannot be identified or delimited in any definable way. Something of this nature is currently being theorized by philosophers from Jean-Luc Nancy to François Jullien and Giorgio Agamben, in various modes, as "the common" (Nancy 2010; Jullien 2008). The "nothing," or no determinate identity, that we all share in common is actually worth more in our valuation as human beings than any distinguishing traits or characteristics. It is only by virtue of this common being that we are ultimately—and all equally—valuable.

Crucial to conceiving the common in the West was imagining a being-and a kind of being-without identity because above identity. This metaphysical and theological imagination was keyhistorically to ushering in the conditions permitting the development of democratic society. Thus, the founding principle is not so much equality per se-which requires measurable differentials-as the absolute value of each individual. This indefinable absolute is what is equal about us, not our identities and their specific determinations. Trying to measure and equalize our identitarian determinations, as if "female" had to be made equal in worth to "male" (or even greater in order to compensate for past injustices) effaces qualitative differences which inflect the equally absolute, but indeterminate and incommensurate, worth of each in its own kind. The one being that all share in common is something that transcends all particular determinations. It is truly holy-the social sacred, we might say, borrowing from Émile Durkheim's most essential insight (Durkheim 1912).

Valorizing, instead, the differentials—some of them, like female or non-white or gay-places such determinations into competition with one another, which is absurd. They should be complementary determinations intelligible only through mutual recognition rather than contenders for domination of one over the other. Identities are delimitations of an indeterminate being that is the only positive source of worth. Consequently, instead of being the basis for claiming rights, identities should be evoked, rather, as means of according recognition to distinctive qualities of others. The fact that all individuals have an equal claim to absolute being or value-which, however, has no specific (necessarily oppositional and therefore divisive) determinations-should be taken to signal the endless limitation of our rights by others' rather than their unrestricted claims and unlimited scope.

A strong sense of the mutual limitation of our rights by those of others is needed because of the tendency to absolutize the rights of any given class of individuals who come to self-consciousness and assert themselves, acquiring, thereby, identity and voice, even through such channels of social communication as literary theory itself. All such organs of self-expression, as means of communicating, are the special concern of theory. They are intrinsic to how any identity comes to be significant and to how it signifies itself. But beyond the contingent relativities that determine which individual identities emerge into visibility and self-assertion, there is an ethical question of relation to others, or to the Other (as highlighted, for example, by Emmanuel Levinas's ethics), that forces us to look beyond the absoluteness of self-affirmation on the part of any one individual or group and their claim to value. 
Without this sense of an Other beyond all definable identities, we are constantly at risk of absolutizing ourselves or some specific, exclusive, identitarian class (Halbertal and Margalit 1992). ${ }^{9}$

The seminal inspiration of the human rights movement, for instance, is the idea that certain rights are natural and universal and ought to be guaranteed quite independently of history or social context. They are taken as context-transcendent and are advocated as applicable irrespective of local or regional or cultural or any other contingent norms (Agamben 1995, p. 92ff.). ${ }^{10}$ However, in any explicit and formulated rendition, they are not culturally neutral and do not come from nowhere nowhere (Yu 2009, pp. 351-90; De Bary 2014, pp. 277-325). ${ }^{11}$ Any specific and concrete formulation of what someone declares to be universal and absolute creates a disequilibrium, for other contingent norms are threatened by an absolute. Any system of value might aim at the absolute and universal, but only on condition of not appropriating it for any particular finite code and language.

Disability theory might be pondered here as an illustration. The rights of the handicapped require special attention and provision. There is even an absolute ethical imperative in support of this special consideration. However, when these rights are absolutized in specific forms, they risk infringing on the rights of others. Loading and unloading wheel chairs on buses in major metropolises at peak hours, for example, can cause traffic jams that bring circulation to a standstill (especially when the lift mechanism refuses to function properly). This certainly has to be tolerated up to a point, but there are, nevertheless, limits. Those who are not officially designated as handicapped are, in many ways, weak and vulnerable too. The stresses and strains of public transportation can cause illness and injury to anyone, not just to those certified as disadvantaged and wearing an official badge to that effect. This is where there has to be negotiation and balancing-a weighing of which rights are to take precedence when and where, in consideration of all. Many find themselves confronted today with situations where it is impossible to find a place to park without a handicapped sticker on their car, while rows of handicapped-reserved places remain empty day and night.

One theoretical tendency of movements like disability rights is to create the fiction of a generality of normal people who do not have special needs. But this fiction of the "normal," too, is an invidious labeling. It functions, in effect, to de-privilege those not qualifying for a more advantageous tag or designation. Without question, recognizing certain kinds of disadvantaged or oppressed groups has been the right thing to do in specific times and contexts. An ironic reversal has occurred, however, when, by complaining about being discriminated against through presumably stigmatizing categories, like black or female, a particular identity group is able to exploit its status as minority and presumably disfavored in order to gain advantage and claim special privileges and compensations-for just a tiny sampling of the group, of course, and perhaps to the further disadvantage of the vast majority.

Treating people as tokens of identitarian groups, whether to privilege or to penalize them, inevitably does injustice to individuals. In many competitive activities, like seeking jobs or applying for admission to universities, being in some minority category can prove to be a distinct advantage. The claim for enfranchisement on an equal basis mutates into a garnering of privilege in the name of some particular category or group and its claim to preferential treatment. Easily identifiable, publicly recognized categories become the basis for according special favor, but there are many kinds of weakness and disadvantage that do not fall into such categories, or are at least not easily identifiable as doing so. Most importantly and detrimentally, the level of perception remains focused on general categories such as race or gender and becomes blind to the unique value of individual persons and to what they need and have to offer.

9 In general terms, the danger here is that of idolatry such as negative theology has aimed at exposing and critiquing throughout Western and particularly biblically influenced tradition. This long history is reconstructed in Halbertal and Margalit (1992).

10 Compare critical reflections concerning human rights by Agamben (1995, vol. 1, p. $92 \mathrm{ff})$.

11 Concerns about applying a Western human rights agenda to China, for example, are raised by Yu (2009, pp. 351-90). See also De Bary (2014, pp. 277-325), "Confucianism and Human Rights," "China and the Limits of Liberalism. 
Nature respects the unique value of each person, even in creating inequalities and limited abilities. It is human beings who decide what counts as a disability and calls for compensatory treatment. For nature, certain capacities come with certain bodies and faculties, which are accorded to some and not to others. We may well feel that social justice needs to step in to counteract the arbitrary injustices of nature. However, we are the ones who perceive these aberrant phenomena as injustices, or as demanding correction, rather than just as differentials in capacity such as pertain to any unique individual in relation to others. We choose which differences merit special provisions and compensations.

At this point, we cannot help but perceive a certain arbitrariness that is now legislated by a human politics rather than resulting simply from the arbitrariness of nature in distributing its privileges. Made into law, identity-based legislation produces arbitrary inequalities of its own. And inequality that is produced by artificial means has a different status and moral valence. It entails a new kind of responsibility. We cannot, any more than nature, definitively determine what is fair and justify who gets what. We can only try to set up our own processes of selection as equitably as possible. Ideally, everyone would be entitled to every humanly possible favoring that caring institutions and technological capability can afford. But decisions are made to favor some and not others. Unlike nature, human decision makers can be held accountable to justify their reasons for according preferential treatment to some and not to others.

Treating individuals according to our abstract, general categories violates their uniqueness. Ethically valid reasons concern particular cases and unique individuals rather than class actions. Appealing to the global or world-historical disadvantage of women and non-whites participates in the same sort of mystification that accords whiteness or maleness superiority and privilege on whatever specious basis of presumptive right. To ascribe to ourselves and our interventions any objective kind of justice is short-sighted, self-deceptive moralizing.

What I wish to question with this argument is not the principle of giving preferential treatment to individuals belonging to vulnerable classes but rather the moralizing that typically goes along with it and the sometimes hypocritical pretense that our determinations instantiate an objective "fairness (Asma 2012; Fish 2013)."12 Such a position, instead, has to take responsibility for itself as a certain configuration and exercise of power. It, too, is interested and is all too likely to provoke hostile reaction from others not falling under its special protection. We can say that those reactions are morally wrong and not to be tolerated, and we can even exercise force, if necessary, to contain them. But then we enter into an oppositional logic and ideological conflict and war rather than inviting all to participate in an equitable sharing of common vulnerabilities. Once a certain party presumes to define what is just and right, the spirit of fair-mindedness of which all are capable, but which none has the moral authority to unilaterally impose, is taken over, appropriated, and turned into a political power and even weaponized. Those who dissent from our determination of universal justice can find themselves branded as immoral. They may feel as patent injustice their being stigmatized or even criminalized for refusing to endorse and subscribe to a gendered, racialized agenda that an empowered group has succeeded in establishing as the moral norm.

The elevation of the "rights" of a certain category often takes on a holy and unimpeachable aura. Even to try to balance its claim against those of others is decried and subjected to shaming tactics in the prevailing climate of grievance studies at the university. Of course, these social climates are mutable and subject to volatile winds of political change, but a certain liberal orthodoxy, where it achieves

12 Some perverse tendencies of overtly egalitarian ideologies inherited from the Enlightenment are examined by Asma (2012). Asma champions a different, less calculable ideal of justice against narrow Enlightenment ideas of a positive and demonstrable fairness and equality that ignore the pervasiveness and inescapability of exceptions. This is inevitable where all identitary terms are but fictions. For related reasons, Fish (2013) openly advocates favoritism. 
hegemony, often tends to impose itself as beyond question and to silence anyone who would dare to think differently (Bawer 2012). ${ }^{13}$

Reversing the direction of discrimination while continuing to treat individuals in terms of classes is not a very satisfactory solution. Women banding together to denounce sexual abuse or harassment perpetrated by men is certainly necessary for political progress, but it tends also to deepen the stereotyped treatment of both sexes divided into victims and predators. Only a universal basis beyond the male-female dichotomy, and thus beyond defined identities, can motivate all to renounce violence rather than simply will to turn it in the other direction in order to gain revenge, which perpetuates an endless cycle. Only such a universal basis can enable the particular charism of being female or male to express itself in mutually saving and gracing ways that will not be condemned to sinister cycles of exploitation and retaliation.

The tyranny of identity, of the recognizable category and label, has become pervasive in our society. People are treated in terms of their definable characteristics and the discriminating traits by which they fall into designated groups. The definable and categorizable becomes the carrier of political capital. The digital logic of 1 or 0 , such as reigns in administrative milieus, furthermore, dictates that you either are or are not disadvantaged and entitled to special assistance. It ignores the fact that all of us are these things, rather, in various ways and in infinitely varying degrees and according to variable circumstances.

Those without any special label may be the most apt not to be represented. A politics that manipulates power or advantages always on behalf of what is defined and categorized builds something more than just a prejudice into the system. It installs something rather of the order of general systemic distortion. In fact, these are the same epistemological tendencies that Cornel West analyzed as having engendered white supremacy and the demotion of blacks as a race in the first place: "observing, comparing, measuring, and ordering of the physical characteristics of bodies" led to a certain type being perceived as ideal and normative (West 1982, p. 49).

To this extent, a fixation on the special categories of identity politics entails the perpetuation of an invidious and oppressive system. The problem was not just that of the supremacy of whites over blacks but, even more fundamentally, the blinkered perception of human beings through such reductive categories. The latter tends to blind us to the entire dimension of the indefinable as the only true source of human dignity and worth. Once we are seeing only black or white, male or female, either/or, we have lost sight of what is neither the one nor the other and yet is the only true basis of the infinite value of each.

\section{The Indefinably Common and Incommensurable}

This sort of epistemic problem has long been a cause of concern in national politics steered, or at least deflected, by special-interest groups. Pretending that all that exists and needs to be cared for humanly is parceled out into definable groups with labels blinds us to a deeper level of human and even non-human reality. As in many of the cruder versions of Marxism, the mistake is made of treating all reality, including ourselves, as at the disposal of society, as exhaustively comprehended by our categories. We need, instead, to foster greater sensitivity towards the deep vulnerabilities in the human body and psyche that remain unidentified in explicit social terms, as well as to what transcends the human and thereby resists the totalizing systems of human beings and yet nevertheless demands to be respected as well. Ecology or nature and divinity or life itself are prime examples (Morton 2010). ${ }^{14}$

In the postmodern perspective, there is a degree of choice about identities, since they are recognized as constructed. It is not that we have no identities, but we do not simply have them. We own them and

13 Bawer (2012) exposes the moral hypocrisy and intellectual bankruptcy of a certain liberal elite. Some academics make privileged careers for themselves by pretending to represent the victims.

14 The non-human is viewed from an eco-philosophical angle by Morton (2010) 
appropriate them in ways that we have to choose freely. This means that we bear responsibility also for what they exclude. We have to look beyond the bounds of the identities that we have constructed and not be mesmerized by our own idols, since they are made with human hands. Like the dead God who, once dead, becomes an obsession present everywhere, according to Freud (Freud 1950), so the deconstructed identity is not done away with but is made over into an obsession with identity, an obsession that threatens to eclipse concern for what is not so easily identifiable. In a more productive reaction to this situation of shattered and reasserted identity, we should accept the challenge to take responsibility for our identities. This is a prerequisite for our being able to see past identity and attain to the truly universal beyond all its divisive designations. I conceive this task as one of learning how to think past the logic of exclusivities_or perhaps, in some sense, past logic itself as per se based on exclusions. This is a matter of how to unthink our thinking itself and its inescapably invidious, exclusionary logics.

Ernesto Laclau, for one, has struggled with the challenge of recuperating some sense of universal responsibility to all from beyond the shattering of a certain European hegemonic ideology of the universal (Laclau 1996, 1999, pp. 131-45). ${ }^{15}$ European colonialism was, after all, very particular in its conception of its "civilizing" mission. Situated between poststructuralist ideologies of difference and traditional Marxist doctrines based on a monolithic conception of historical universality, Laclau analyzes the paradoxes of identity as pointing negatively to a universality that is necessarily lacking. Particular identities require always an oppositional positing of their contraries and, to that extent, are dependent on them. They are, to this degree, incapable of true universality. True (if not classically logical) universality is incommensurable with every particularism, and to this extent the universal cannot even exclude particularity but, instead, becomes variously incarnate in it.

My analysis of identity politics is based on religious tradition and cultural theory rather than on a neo-Marxist social vision. Nevertheless, it agrees with Laclau's apophatic logic in acknowledging the incommensurable. Laclau concludes that the "non-resolution" of the paradox of a universality that is incommensurate with every particularity and yet depends on the particular in order to exist at all is the "pre-condition par excellence of democracy" (Laclau 1999, p. 145). His purpose is to resist the monolithic rejections of universalism as irrevocably tainted by a particular ethnocentric history of dominant classes in the Occident. He is moving toward what I call an apophatic rethinking of identity in a horizon of universality.

Analyses like Laclau's, which invoke the universal as a "constitutive void" ("vide constitutif") or "empty signifier" ("signifiant vide"), help us to recognize that the universal is not to be identified with any one of its possible formulations. It has no identity but is rather the "something more and different" that is always missing in any and every formulation of identity. On these grounds, we can recognize that there is always a degree of non-identity in every identity that we may choose to recognize or assume. The non-identical should be recognized as our deepest being and "nature."

Here, again, nature may come back from beyond the obliterations that modern and postmodern culture have perpetrated against it. It may then be that race, for example, should be a criterion in hiring, but it should also be recognized as an artificial construct used for pragmatic purposes: the hiring agency must take responsibility for its use of such a criterion. This bias in policy should not be mystified as natural justice. It is the result of a certain politics. And politics means taking up the cause of a certain party. But, in that case, it needs to be done in the interest of keeping an equal measure for all, just as God is "no respecter of persons" according to an older Scriptural idiom (Acts 10:34; Romans 2:11, etc.). This means giving precedence to what is not differentially defined about a person, to what is not the mask (persona, in its original Greek sense) that (mis)identifies an individual.

15 Laclau (1999, pp. 131-45). There is an English version in Rajchman (1995). It belongs together with Laclau (1996) rethinking of the relations between universality and particularity. 
Without careful attention to the non-identifiable, to what is indeed no person and remains virtually invisible because unidentified and unidentifiable by discourse, identity politics are at risk of becoming an attempt to make exclusionary tactics work in favor of a group that has been harmed by those very tactics in the past rather than to escape-or at least to provisionally exit-from the system of binary opposition and oppression. The result can be, at best, the attempt to achieve retribution for past wrongs rather than to right the system for the future. In the interests of all, the point is not, or should not be, whether the person hired or otherwise preferred is black or female or gay.

I wish, then, to voice a plea on behalf of whoever or whatever is nothing and no one identifiable. The non-identity of what is deepest and most precious in human beings is apt to be forgotten for lack of any identifying label or discursive marker. This non-identity is in all of us, and only cherishing it can motivate humans to unite universally in solidarity with one another. The order of identity is an order of discourse and is differential. It is apt to distort or suppress the other order or disorder that invisibly subtends every discursive artificial system of instituted significances. This other, separate, literally "sacred" sphere of existence is what Georges Bataille seeks to gain access to through sacrifice and festival (Bataille 1943). It is also what Michel de Certeau traces through Christian traditions in his "heterologies" (De Certeau 1987). It is what has been held sacrosanct as the divine throughout the history, and especially the pre-history, of cultures. Axial Age cultures bear witness to this transcendent source of culture at the dawn of critical consciousness (Bellah and Joas 2012).

I have endeavored to show here how certain recent, let us say, loosely, "postmodern" theorists of identity have brought out ways in which the very notion of identity escapes treatment by an objective logic that would enable it to be deliberately advocated and directly established in a straightforward way. And yet, the practical applications of identity politics often still tend to conceive of identity in individualistic terms and as something other than just a relation. They conceive of it as something substantive or reified rather than relational, to the extent that they make unilateral assertions of identity. The dialectic between the claims of identity in the style of the Enlightenment and the deconstruction of identity, following the insights of post-structuralist theory, can be traced, as we have seen, in some of the most highly influential work on the politics of identity down to Cornel West and Judith Butler (Butler 1992). Following Gayatri Spivak, Butler sees identity terms as "necessary errors" and identifies the necessity for a "self-critical dimension" in every use of such terms because of the risk of their becoming invidiously exclusionary:

As much as it is necessary to assert political demands through recourse to identity categories, and to lay claim to the power to name oneself and determine the conditions under which that name is used, it is also impossible to sustain that kind of mastery over the trajectory of those categories within discourse. This is not an argument against using identity categories, but it is a reminder of the risk that attends every such use. The expectation of self-determination that self-naming arouses is paradoxically contested by the historicity of the name itself: by the history of the usages that one never controlled, but that constrain the very usage that now emblematizes autonomy; by the future efforts to deploy the term against the grain of the current ones, and that will exceed the control of those who seek to set the course of the terms in the present.

(Butler 1993, pp. 227-28)

These remarks point to the necessity of negotiating a new status for identity claims and terms. Identity can come back in postmodern thought as an indefinable sort of non-identity. Identity is one of the primary concepts of metaphysical tradition, but it can also return after the post-structuralist critique of metaphysics in an unsettled and unsettling form as dis-identity, a kind of return of the repressed. Non-identity ("das nicht Identische") is a key concept-or rather the key to moving beyond conceptual thinking altogether-for Theodor Adorno in his philosophy of "negative dialectics" 
(Adorno 1966, 1990). ${ }^{16}$ Of course, we still need to think in terms of identities in order to think our way beyond them. All this can be considered to lie broadly within the tradition of the Enlightenment and indeed emphasizes the self-critical turn whereby the Enlightenment illuminates and exposes its own myths, including that of identity, when it is construed as a sort of pure or natural entity. Enlightenment, along this critical path of thinking, has to think against Enlightenment itself and so turn itself into the dialectic of Enlightenment.

Clearly, fundamental issues in philosophy that do not admit of definitive answers, but turn rather on questions that remain inevitably controversial, are engaged here. Yet, in any case, it is imperative that we recognize something as not resolvable in verbal terms at the bottom of all our discourses. A crucial and difficult question of philosophical logic is whether that indefinable Namelessness which elusively appears here should be recognized as the absolutely and indescribably unique and singular or, alternatively, as the absolutely universal. However that may be, the difference in question is not predicative but appellative: like the proper name as it is theorized by Franz Rosenzweig, such difference names unique or universal being that cannot be said nor be linguistically determined at all (Rosenzweig 1988). ${ }^{17}$ It can, nevertheless, be invoked or called upon as a difference that could be made by one who opts to respond to its silent appeal.

Issues of recognizing racial, gender, and class differences have been cast in a new, original light by political and cultural theorists thinking along these apophatic, non-identitarian lines (Rajchman 1995). Creative writers, too, have made indispensable contributions. For Homi Bhabha, post-colonial poets Derek Walcott and Sonja Sanchez, responding to their heritage in the "disjunctive present," show how "claims to identity must never be nominative or normative" (Bhabha 1995, p. 55). Somewhat similarly, Zygmunt Bauman has been influential in bringing into focus the "modern liquidity" of identity (Bauman 2001, 2004).

I would highlight, furthermore, especially the theologically oriented approaches by feminist thinkers opening up a space for the apophatic, which transcends the oppositional logic of much now institutionalized gender discourse (Keller 2007; McFague 2007; Fiorenza 2007; Johnson 1992). There is a new wave of American feminist theologians who are overcoming traditional tensions that polarized the European and American approaches of an earlier generation. Attunement to a quasi-theological dimension of indeterminacy enables them to converge with French feminism and its pursuit of an indefinitely indeterminate ideal of "écriture" or writing (Irigaray 1977, 1987). ${ }^{18}$ French feminists, including eminently Luce Irigaray and Hélène Cixous, have long pursued a re-inscription of female identity, whereby the identity of woman is not simply asserted against that of man as equal and therefore commensurable-since that is typical of the oppositional logic that has proved inadequate in the postmodern view-but as irreducibly diverse.

Consequently, one of the most fertile fields for development of an apophatic approach today is found in gender studies. A powerful argument for why any gender identity needs to project an ideal for itself to identify with in the shape of its own "God" ("Dieu") is made by Luce Irigaray in "Divine Women" ("Femmes divines") (Irigaray 1985; Ward 1997, pp. 191-214). This reflection offers a starting point for developing an apophatic approach also to gay rights and transgender consciousness. The apophatic is the key to making these movements about connecting with other groups and identities so that they valorize one another reciprocally through common relation to an absolute non-identity above identity (such as "God"). This "divinity" is necessary as an ideal shared in common and potentially uniting all. When identity is expressed and defined it becomes exclusive. Only in being an avenue towards the inexpressible and nonidentifiable can it serve for harmony and unity. The paradox, however, is that identity as negated can be conducive to and can actually be necessary for surpassing

\footnotetext{
6 Adorno (1990, pp. 108, 113-14, 121-22, 171) uses the term "das nicht Identische".

17 See especially section 174 on the proper name ("der Eigenname").

18 Irigaray (1977) approaches the feminine gender through negation and its inexhaustible. See also (Irigaray 1987, pp. 420-37).
} 
the impasses and competitive frictions that are generated by identity when it is used in oppositional forms of thinking. There is a dialectical relation between identity and nonidentity-they require and imply each other.

A highly sophisticated sociological analysis of the prime importance of the unidentified or "unmarked" in the construction of social dynamics and particularly of religion as a symbolic system is developed by Niklas Luhmann. Luhmann, in effect, systematically constructs the social logic of the unidentifiable, or what I would call the apophatic, as a necessary key to interpreting every identity. (Luhmann 1997, 2002). Every mark of identity marks itself against the unmarked, and it is the relation between the marked and the unmarked that originates the peculiar domain of religion (Luhmann 2000).

The non-identical generally seems to be hardly worth worrying about. It has no face or front, nor any constituency at all, to back it. It tends to become invisible. But if we lose sight of it, the conflicts between different identities can only tragically battle out their differences unto death or, at best, effacement and suppression, and in any case inculpation, of one by the other. Most importantly, it is necessary to discern and retain this elusive dimension of the non-identical in order to deal in a more supple manner with the identities that are overtly declared: we must remember that such identities do not declare everything and that they, in fact, inevitably dissemble what is actually most important about each and every one of us.

This existential paradox underlies the critical questioning of science vis-à-vis humanities disciplines, notably theology, in which identity proves to be relational and can never be definitively pinned down in finite, context-free terms. Modern science is based on positively definable properties and identities, but its deeper truth and meaning emerge only when it is viewed against this broader background. Theology, especially negative theology, turns out to be particularly illuminating on these questions of identity because they remain rooted in the mystery of who we are.

Funding: This specific research received no external funding.

Conflicts of Interest: The author declares no conflict of interest.

\section{References}

Adorno, Theodor. 1966. Negative Dialektik. Frankfurt am Main: Suhrkamp. Translated by E. B. Ashton. 1973. As Negative Dialectics. New York: Continuum.

Adorno, Theodor. 1990. Ästhetische Theorie. Frankfurt am Main: Suhrkamp.

Adorno, Theodor, and Max Horkheimer. 1944. Dialektik der Aufklärung: Philosophische Fragmente. Amsterdam: Querido. Translated by Edmond Jephcott. 2002. As Dialectic of Enlightenment: Philosophical Fragments. Edited by Gunzelin Schmid Noerr. Stanford: Stanford University Press.

Agamben, Giorgio. 1995. Homo Sacer: Il Potere Sovrano e la Vita Nuda. Turin: Einaudi, vol. 1.

Agamben, Giorgio. 2000. Il Tempo Che Resta: Un Commento Alla Lettera ai Romani. Turin: Bollati Boringhieri. Translated by Patricia Dailey. 2005. As The Time that Remains: A Commentary on the Letter to the Romans. Stanford: Stanford University Press.

Alcoff, Linda Martín, Michael Hames-García, Satya P. Mohanty, and Paula M. L. Moya, eds. 2006. Identity Politics Reconsidered: Future of Minority Studies. New York: Palgrave MacMillan.

Asma, Stephen T. 2012. Against Fairness. Chicago: University of Chicago Press.

Badiou, Alain. 1997. Saint Paul: La Fondation de L'universalisme. Paris: Presses Universitaires de France. Translated by Ray Brassier. 2003. As Saint Paul: The Foundation of Universalism. Stanford: Stanford University Press.

Bataille, Georges. 1943. L'expérience Intérieure. Paris: Gallimard.

Bauman, Zygmunt. 2001. Identity in a Globalizing World. Social Anthropology 9: 121-29. [CrossRef]

Bauman, Zygmunt. 2004. Identity. Edited by Benedetto Vecchi. Cambridge: Polity.

Bawer, Bruce. 2012. The Victim's Revolution: The Rise of Identity Studies and the Closing of the Liberal Mind. New York: HarperCollins.

Bellah, Robert N., and Hans Joas, eds. 2012. The Axial Age and Its Consequences. Cambridge: Belknap Press of Harvard University Press.

Bhabha, Homi. 1995. Freedom's Basis in the Indeterminate. Edited by John Rajchman. London: Routledge, pp. 47-62. 
Boyarin, Daniel. 1994. A Radical Jew: Paul and the Politics of Identity. Berkeley: University of California Press.

Butler, Judith. 1992. Contingent Foundations: Feminism and the Question of 'Postmodernism'. In Feminists Theorize the Political. Edited by Judith Butler and Joan Scott. New York: Routledge.

Butler, Judith. 1993. Critically Queer. In Bodies that Matter: On the Discursive Limits of "Sex". New York: Routledge. Caputo, John, and Linda Martín Alcoff, eds. 2009. Saint Paul among the Philosophers. Bloomington: Indiana University Press.

Caputo, John, and Michael J. Scanlon, eds. 2007. Transcendence and Beyond: A Postmodern Inquiry. Bloomington: Indiana University Press.

Carlson, Thomas. 2008. The Indiscrete Image: Infinitude and the Creation of the Human. Chicago: University of Chicago Press.

De Bary, Wm Theodore. 2014. The Great Conversation: Education for a World Community. New York: Columbia University Press.

De Certeau, Michel. 1987. La Faiblesse de Croire. Paris: Seuil.

De Vries, Hent. 1989. Theologie im Pianissimo \& Zwischen Rationalität und Dekonstruktion: Die Aktualität der Denkfiguren Adornos und Levinas. Kampen: J. H. Kok. Translated by Geoffrey Hale. 2005. As Minimal Theologies: Critiques of Secular Reason in Adorno and Levinas. Baltimore: Johns Hopkins University Press.

De Vries, Hent. 1999. Philosophy and the Turn to Religion. Baltimore: Johns Hopkins University Press.

Deleuze, Gilles. 1968. Différence et Répétition. Paris: Presses Universitaires de France.

Derrida, Jacques. 1967. L'écriture et la Différence. Paris: Seuil.

Durkheim, Émile. 1912. Formes Elémentaires de la Vie Religieuse. Translated by Karen E. Fields. 1975. As The Elementary Forms of Religious Life. New York: Free Press.

Fiorenza, Elizabeth Schüssler. 2007. God the Many-Named: Without Place and Proper Name. In Transcendence and Beyond: A Postmodern Inquiry. Edited by John Caputo and Michael J. Scanlon. Bloomington: Indiana University Press.

Fish, Stanley. 2013. Favoritism is Good. New York Times. January 7. Available online: http://opinionator.blogs. nytimes.com/2013/01/07/favoritism-is-good (accessed on 14 August 2019).

Flax, Jane. 1993. Disputed Subjects. London: Routledge.

Franke, William. 2007. On What Cannot Be Said: Apophatic Discourses in Philosophy, Religion, Literature, and the Arts. 2 vols, Notre Dame: University of Notre Dame Press.

Freud, Sigmund. 1950. Totem und Tabu (1912/13) and Der Mann Moses und die Monotheistische Religion (1939). In Gesammelte Werke. Frankfurt am Main: Fischer.

Habermas, Jürgen. 1985. Der Philosophische Diskurs der Moderne: Zwölf Vorlesungen. Frankfurt am Main: Suhrkamp. Translated by Frederick G. Lawrence. 1988. The Philosophical Discourse of Modernity: Twelve Lectures. Cambridge: MIT Press.

Halbertal, Moshe, and Avishai Margalit. 1992. Idolatry. Translated by Naomi Goldblum. Cambridge: Harvard University Press.

Hall, Stuart. 2003. Introduction: Who Needs 'Identity'? In Questions of Cultural Identity. Edited by Stuart Hall and Paul du Gay. London: Sage Publications.

Heller-Roazen, Daniel. 2017. No One's Ways: An Essay on Infinite Naming. New York: Zone Books.

Hooks, Bell. 1990. Yearning: Race, Gender, and Cultural Politics. Boston: South End Press.

Irigaray, Luce. 1977. Ce Sexe Qui N'en est Pas Un. Paris: Minuit.

Irigaray, Luce. 1985. Femmes Divines. Critique 454: 294-308.

Irigaray, Luce. 1987. Égales à Qui? Critique 480: 420-37.

Johnson, Elizabeth. 1992. She Who Is: The Mystery of God in Feminist Theology. New York: Crossroad.

Jullien, François. 2008. De L'universel, de L'uniforme, du Commun et du Dialogue Entre Les Cultures. Paris: Fayard. Translated by Michael Richardson, and Krzysztof Fijalkowski. 2014. As On the Universal: The Uniform, the Common and Dialogue between Cultures. London: Polity Press.

Keller, Catherine. 2007. Rumors of Transcendence: The Movement, State, and Sex of 'Beyond'. In Transcendence and Beyond: A Postmodern Inquiry. Edited by John Caputo and Michael J. Scanlon. Bloomington: Indiana University Press.

Laclau, Ernesto. 1996. Emancipation(s). London: Verso.

Laclau, Ernesto. 1999. L'universalisme, le Particularisme et la Question de L'identité. La Revue du MAUSS 13. Translated by John Rajchman. 1995. As The Identity in Question. New York: Routledge, pp. 131-45. 
Luhmann, Niklas. 1997. Die Gesellschaft der Gesellschaft. Frankfurt am Main: Suhrkamp.

Luhmann, Niklas. 2000. Die Religion der Gesellschaft. Frankfurt am Main: Suhrkamp.

Luhmann, Niklas. 2002. Einführung in Die Systemtheorie. Heidelberg: Carl Auer Verlag.

McFague, Sallie. 2007. Intimations of Transcendence: Praise and Compassion. In Transcendence and Beyond: A Postmodern Inquiry. Edited by John Caputo and Michael J. Scanlon. Bloomington: Indiana University Press. Milbank, John, Slavoj Žižek, Creston Davis, and Catherine Pickstock. 2010. Paul's New Moment: Continental Philosophy and the Future of Christian Theology. Grand Rapids: Brazos.

Morton, Timothy. 2010. The Ecological Thought. Cambridge: Harvard University Press.

Nancy, Jean-Luc. 2010. Déconstruction du Christianisme. L'Adoration. Paris: Galilée, vol. 2.

Rajchman, John, ed. 1995. The Identity in Question. New York: Routledge.

Rosenzweig, Franz. 1988. Der Stern der Erlösung. Frankfurt am Main: Suhrkamp. Translated by William W. Hallo. 1985. As The Star of Redemption. Notre Dame: University of Notre Dame Press. First published 1921.

Santner, Eric. 2015. The Weight of All Flesh: On the Subject-Matter of Political Theology. Oxford: Oxford University Press. Sen, Amartya. 2006. Identity and Violence: The Illusion of Destiny. New York: Norton.

Taylor, Mark C. 1984. Erring: A Postmodern Atheology. Chicago: University of Chicago Press.

Ward, Graham. 1997. The Postmodern God: A Theological Reader. Oxford: Blackwell.

Weber, Max. 1992. Die Protestantische Ethik und der Geist des Kapitalismus. Tübingen: Mohr. Translated by Talcott Parsons. 1930. As The Protestant Ethic and the Spirit of Capitalism. London: Routledge. First published 1905.

West, Cornel. 1982. A Genealogy of Modern Racism. In Prophesy Deliverance! An Afro-American Revolutionary Christianity. Philadelphia: Westminster Press.

Yu, Anthony C. 2009. China and the Problem of Human Rights: Ancient Verities and Modern Realities. In Comparative Journeys: Essays in Literature and Religion East and West. New York: Columbia University Press. Žižek, Slavoj. 2000. The Fragile Absolute—or, Why Is the Christian Legacy Worth Fighting For? London: Verso.

(C) 2019 by the author. Licensee MDPI, Basel, Switzerland. This article is an open access article distributed under the terms and conditions of the Creative Commons Attribution (CC BY) license (http://creativecommons.org/licenses/by/4.0/). 